\title{
Communication
}

\section{Increasing the Effectiveness of the "Great Green Wall" as an Adaptation to the Effects of Climate Change and Desertification in the Sahel}

\section{David O'Connor ${ }^{1, *}$ and James Ford ${ }^{2}$}

1 Redpath Museum, McGill University, 859 Sherbrooke Street West, Montreal, QC H3A 0C4, Canada

2 Department of Geography, McGill University, 805 Sherbrooke Street West, Montreal, QC H3A 0C4, Canada; E-Mail: james.ford@mcgill.ca

* Author to whom correspondence should be addressed; E-Mail: david.oconnor@mail.mcgill.ca; Tel.: +1-514-562-7350; Fax: +1-514-398-7437.

External Editor: Marc A. Rosen

Received: 21 August 2014; in revised form: 28 September 2014 / Accepted: 28 September 2014 / Published: 16 October 2014

\begin{abstract}
The Great Green Wall (GGW) has been advocated as a means of reducing desertification in the Sahel through the planting of a broad continuous band of trees from Senegal to Djibouti. Initially proposed in the 1980s, the plan has received renewed impetus in light of the potential of climate change to accelerate desertification, although the implementation has been lacking in all but two of 11 countries in the region. In this paper, we argue that the GGW needs modifying if it is to be effective, obtain the support of local communities and leverage international support. Specifically, we propose a shift from planting trees in the GGW to utilizing shrubs (e.g., Leptospermum scoparium, Boscia senegalensis, Grewia flava, Euclea undulata or Diospyros lycioides), which would have multiple benefits, including having a faster growth rate and proving the basis for silvo-pastoral livelihoods based on bee-keeping and honey production.
\end{abstract}

Keywords: climate change; adaptation; Africa; desertification; land reclamation 


\section{Introduction}

Sub-Saharan Africa (SSA) is believed to be one of the most vulnerable regions globally to climate change [1]. Warming temperatures and changing precipitation regimes are projected to exacerbate natural hazards, accelerate desertification, increase exposure to infectious diseases, compromise food and water security and accelerate the degradation of ecosystem services [1-4]. Significant economic and humanitarian costs are projected, with climate change compounding ongoing development challenges in low income nations [2,5].

Semi-arid regions of SSA, the Sahel in particular, have been identified as "hotspots" of enhanced vulnerability to climate change [6,7]. This reflects the already marginal environment, high dependence on rain-fed agriculture, ongoing desertification challenges and limited adaptive capacity of socio-economic systems [2]. Given the inevitability of some degree of climate change and already observed impacts, adaptation has been prioritized for climate policy in SSA. To this end, significant advances in adaptation have been made over the last decade, including the establishment and disbursement of adaptation funds through the UN Framework Convention on Climate Change (UNFCCC), completion of National Adaptation Programs of Action (NAPAs), initiation of National Adaptation Plans (NAPs), mainstreaming of adaptation into development projects and the emergence of a large body of scholarship examining vulnerability to help direct adaptation efforts [8-13]. A variety of adaptations have been identified, evaluated and in some case implemented, ranging from those explicitly designed to reduce vulnerability to projected change, to interventions that address the underlying determinants of climate vulnerability [11,14]. Many adaptations are being undertaken at the community-level, funded by non-governmental organizations (NGOs) and donors, combining both hard responses aimed at specific risks of climate change and requiring significant capital investment and soft responses that are achieved through changes in policy, legal or administrative means that decrease vulnerability, with limited evidence of large-scale/trans-boundary adaptations [7,15].

One example of a large-scale adaptation is the Great Green Wall (GGW), a proposal for a continuous band of trees stretching across the Sahel to reduce desertification by moderating temperatures, wind speeds and soil erosion, while increasing local microclimate humidity for agriculture [16-21]. The idea was initially proposed in the 1980 s over concerns of desertification and received renewed attention in the early 2000 s as a potential adaptation to moderate the impacts of projected future climate changes. While the plan has suffered from a lack of funding and political will, we believe the central idea of the GGW has significant potential for adaptation: similar programs have been developed in other regions (e.g., China, New Zealand) and have been successful in reducing, and in some cases reversing, desertification $[16,17,19,22-26]$. However, we believe that the GGW needs modifying if it is to be effective, obtain the support of local communities and leverage international support. Specifically, in this paper, we focus on the vegetational composition of the proposed GGW, arguing that planting shrubs as opposed to trees would be more effective. We begin by profiling the problem of desertification in the Sahel, before reviewing the GGW plan as currently envisioned, and then propose our plan based on shrub planting. 


\section{Desertification in the Sahel}

Desertification can be defined as the process of soil degradation in arid, semi-arid and dry sub-humid areas, resulting from several factors, including climatic variation and human action, and which involves the loss of biological or economic productivity of cropland, pasture, wetlands, forests or woodlands [27]. However, there has been a continued debate regarding desertification in the Sahel. While there has been evidence of the increased encroachment of the Sahara desert into Sub-Saharan Africa and decreased tree-cover and vegetation [28], there have also been arguments that greenness in these semi-arid areas has been increasing over the last 25 years [29]. In this paper, we focus specifically on the process of soil degradation in arid, semi-arid and dry sub-humid areas, resulting from several factors, including climatic variation and human action, and which involves the loss of the biological or economic productivity of cropland, pasture, wetlands, forests or woodlands [30]. For decades, desertification has been identified as one of the most pressing challenges facing the Sahel, with a variety of factors making the region particularly sensitive [31-33]. Biophysically, the Sahel is a semi-arid transition zone between the Sahara desert and tropical Africa. With a rainy season of 3-4 months and annual rainfall between and $600-1000 \mathrm{~mm}$, it has a history of significant climatic variability, punctuated with significant drought [34]. Just over 5500 years ago, the area was humid with lush amounts of vegetation [35]. However, minor changes in precipitation may lead to the most sensitive species being lost. This change in plant biodiversity can then lead to a failure in vegetation feedback as vegetation cover shifts and the interaction between plants and the climate changes. This then resulted in a cascade event and the development and subsequent expansion of the Sahara desert [35,36]. It is suspected that had biodiversity been maintained, biological systems could have prevented the encroachment of the desert [35,36]. In more recent years, the Sahel has experienced a series of wet years, but several areas are currently under prolonged drought, and more variability and decreased precipitation is projected with future climate change. Human factors are superimposed on this high climatic variability, with high levels of poverty, population growth and conflict across many regions of the Sahel, along with a high dependence of rain-fed agriculture. Poor land management techniques, over grazing, lack of water conservation strategies and human-initiated bushfires have all been identified as interacting with biophysical factors to create desertification [37], exacerbated by the disruption of traditional land management practices originating in the colonial era [38-42].

Grazing pressures, in particular, have resulted in soil compaction, erosion and a transition from high quality shrub and grazing lands to low-quality, low-value grasslands [43]. In Gambia, for example, fallow lands have been significantly reduced by a need to increase agricultural output [44], and in Nigeria, livestock populations grew 11-fold between 1950 and 2006, with the grazing needs of $>66$ million animals greatly exceeding the capacity of the grasslands [45]. As a result of the increased need for agricultural output, cultivation has been expanded to marginal, hilly and mountainous lands and wetlands across these areas. Furthermore, in many regions, the primary source of cooking fuel is wood harvested from native and non-agricultural vegetation, especially from forests. Superimposed on current drivers of desertification, SSA is also expected to have an increase in population from 1.4 billion to 2.4 billion by 2050 [46]. There is continued debate on population growth acting as a driver for land use changes, however. The land use decisions of individuals farmers may play a greater role in driving changes of land use than population growth alone [47], and drivers of land use change may be distant 
and the result of socio-economic factors from beyond the regional or national level [48]. Reflecting these broader socio-economic-demographic trends and climate projections, it is widely acknowledged that interventions are needed to stabilize current trends and decrease sensitivity to climate change impacts.

\section{The Great Green Wall}

One of the main approaches proposed for tackling desertification involves the creation of green belts and the planting of trees and other vegetation, which then function as natural barriers to desertification by reducing wind speed, stabilizing soil and increasing soil humidity. To this end, a widely discussed program to address desertification in the Sahel is the building of a "Great Green Wall" (GGW). The idea of a Great Green Wall in Africa was ratified at the World Day to Combat Desertification and Drought in 2002 when 11 countries of the Sahel signed the Convention Creating the Pan African Agency for the Great Green Wall. As of 2011, U.S. \$115 million has been allocated to the initiative from a diversity of organizations and governments. The recent increased interest in the GGW reflects concerns over desertification and biodiversity loss in the context of climate change, with significant implications for food security, along with growing recognition that past efforts by the UN Convention to Combat Desertification (UNCCD) have not met their objectives [49]. The GGW project itself is already being implemented, but in a piecemeal fashion: to date, there has been major land reclamation within Senegal and Niger through the GGW, restoring 27,000 and five million hectares, respectively [49].

The original intent of the GGW was to create a partnership that, with support from international organizations, would work to halt and reverse desertification and land degradation [50]. The GGW emphasizes that environmental protection, societal well-being and economic gain must go hand-in-hand and that it is only through ecosystem protection that current livelihoods can be maintained, with the development and enhancement of silvo-pastoral systems a key component of the GGW. As such, the initiative represents more than just a wall of trees, encompassing a wide range of environmental and development issues. Although the GGW has been proposed as an adaptive strategy to climate change, it could also have important benefits for mitigation through the provision of substantial carbon sequestration through large-scale planting. This would also allow for nations involved in the GGW to potentially sell carbon credits through the international climate regime evolving through negotiations in the UNFCCC.

While international support has been leveraged for the GGW, opposition to the project at local and international levels has mounted, arguing that the initiative has marginalized local people in decision making, is focusing on turning currently productive agricultural land to tree monocultures, will further stress the water system and may result in a loss of traditional livelihoods [51-53]. Moreover, it has been argued that an absence of local buy-in by communities and regional decision makers will significantly undermine the long-term sustainability of the program [54]. Indeed, other similar initiatives from Asia demonstrate that to be successful, the buy-in of local communities is essential and that partnerships must be created between government, local communities and technical and financial partners [26]. 


\section{Revising the "Great Green Wall"}

\subsection{Shrubs vs. Trees}

The GGW, as currently envisioned, proposes that the first step is the planting of a $15-\mathrm{km}$ wide forested band composed of a mixture of native tree species that would traverse the African continent from Senegal to Djibouti, along the southern limit of the Sahara desert. While forests are crucial to blocking desert winds and increasing atmospheric and soil humidity [21], we believe that other plant species would more likely be effective in addressing desertification, have fewer environmental side effects, have greater commercial usage and provide the basis for stronger local level support. Our concern over the current plan reflects the focus on using tree species, including members of the family, Acacia, which have slow growth speeds and high local value as cooking fuel, which may compromise the long-term success of the program and the return on investment if the aim is to moderate/reverse desertification. Particularly in regions of high poverty, and a high demand for fuel wood, high attrition rates of forest have been documented in other regions [55,56], and resources for protecting trees from illegal harvesting are not currently factored in to the GGW. As an alternative to slow-growing tree plants, we therefore propose that shrub plants of sufficient fully-grown height offer an alternative/compliment to the current focus on trees alone. Shrubs have a number of advantages over trees as the basis of the GGW.

Firstly, the higher growth rates of shrubs as early colonizing plants would mean that land reclamation and recovery would be more likely to keep pace with current projections of climatic change. In areas where plant life has been removed, either from natural or human causes, shrubs are often a primary pioneer species, often establishing years before trees and able to reach maturity within a fraction of the time compared to tree species [57]. The rapid establishment and maturation of shrubs would ensure that investment into these areas would be sufficient to maintain current lifestyles and could result in significant improvements in the agricultural, economic and environmental impacts of the GGW [16].

Secondly, shrubs generate a variety of biological interactions, which are likely to improve outcomes and increase the returns on investment. Similar to trees, shrubs provide shade and windbreaks that increase soil humidity, allowing other plants to flourish in these areas [18]. It has been demonstrated, for example, that in arid areas with little cloud cover, shrubs can produce microclimate conditions that are up to $20^{\circ} \mathrm{C}$ cooler than the surrounding bare ground, as well as having lowered rates of evaporation and increased soil humidity [58]. This creates an area with decreased evapotranspiration, increased humidity and better growing conditions for grasses and sedges [21].

Additionally, shrubs have been found to concentrate soil nutrients and to increase the availability of phosphorus, potassium, organic carbon and nitrates [16-19,23,25]. Encroachment of shrubs onto grassland or bare soil, for instance, has been demonstrated to increase aboveground carbon by $61 \%$, soil carbon by $22 \%$, root biomass by $65 \%$, organic soil carbon by $12 \%$, total soil nitrogen by $18 \%$ and available nitrogen by $3 \%$ [59]. These areas below the shrubs provide improved grazing areas, increasing the quantity and quality of available pastoral land [16,17,19,21,23,59] and reducing pressure on the land. In reforestation programs in the Mediterranean, for instance, where shrubs have been used as nursery plants for trees, they have been observed to create a beneficial growth environment, with growth rates of trees 1.8-6.3-times greater than trees grown without nursery shrubs [17]. A study of black Scots pine and black pine seedling survival in a Mediterranean arid zone found that survival was $54.8 \%$ and $81.9 \%$, 
respectively, when beneath shrubs compared to only $21.5 \%$ and $56.8 \%$ in the open [60]. Further, a review of the use of shrubs as nursery plants found that shrubs were most effective in drier, sunnier areas than in wetter, shaded areas [19]. As some shrubs are larger than others, microclimate changes could also be exploited by farmers who would be able to plant crops beneath the shrubs and in the windbreak that they create, with such crops requiring decreased irrigation compared to crops fully exposed to the wind and sun [58].

Shrubs are also a significant carbon sink. A study of new and old-growth shrublands in China, for example, found that carbon sequestration varied from -96 to $-115 \mathrm{gm}^{-2} \mathrm{year}^{-1}$ under normal growing situations [61]. In a comparative study of forest, grassland, shrubland and cropland, also in China, it was found that while grassland and cropland absorbed only $0.007 \mathrm{Pg} \mathrm{C} / \mathrm{a}$ and $0.0125-0.0143 \mathrm{Pg} \mathrm{C} / \mathrm{a}$ respectively, shrubland was a significant carbon sink, absorbing 0.014-0.024 Pg C/a, being surpassed only by forests at $0.075 \mathrm{Pg} \mathrm{C} / \mathrm{a}$ [62].

Thirdly, shrubs may be more sustainable than trees in light of climate projections for the Sahel. An American study of an arid grassland in Texas, Arizona and New Mexico, for instance, suggests that shrubs have increased growth when compared to woody trees given decreases in precipitation and increases in temperature, as predicted under future climate change [20]. However, care should be taken to ensure that the shrub species selected are highly drought resistant, as drought tolerance can vary greatly by species [63]. As a plantation is already required, the transition from planting trees to shrubs should not incur additional financial or logistic strain. A case-study in Sichuan, China, examined the difference between planting trees, planting shrubs or performing no intervention in land reclamation [25]. The study was performed in a wet, cooler area, where trees were expected to grow better than shrub species. However, it was found that shrubland was better at restoring soil quality and required less financial effort to plant and maintain when compared to forestland [25].

\subsection{Flowering Shrubs as a Substitute or Supplement to Trees in a Revised GGW}

Shrubs, then, have multiple potential advantages over trees in forming the GGW. Flowering shrubs, in particular, offer significant potential, as they would allow for the development of associated silvo-pastoral systems. The production of honey and honey-related products, in particular, could offer multiple benefits and underpin development activities for farmers and communities surrounding the GGW. There are several economic opportunities associated with honey products herein. Recently, the medical community has been recognizing the potential applications of honey [64-67]. Honey is the oldest wound dressing material used by humans and has traditionally been used to treat various conditions, including burns, infected and non-healing wounds, ulcers and boils [64-67]. This is due to honey's anti-bacterial capability, its high acidity, osmotic effects, anti-oxidant and hydrogen peroxide content and its stimulation of immunity, as well as other currently unidentified compounds [64]. Sufficient evidence exists to recommend its use in the treatment of acute wounds and mild to moderate burns $[64,66,67]$. These types of medical applications have been found in multiple kinds of honey, including Gelam, Medihoney, Tualang and Manuka [64]. Among the honeys in which medical applications have been determined, Manuka is the most researched and of the most interest. Manuka honey is produced by bees that pollinate and collect nectar exclusively, or nearly exclusively, from flowers of the Manuka tree (Leptospermum scoparium), which is an arid shrub that grows in Australia and New-Zealand. 
Manuka is thus one candidate shrub for reclaiming arid land, as it is a prolific shrub and early colonizer of cleared land [68] and has been used with great success in New Zealand. Here, it was found that Manuka was highly efficient in restoring soil quality, nursing other plant species and improving growing conditions on a variety of degraded terrain, including abandoned mines and areas of extensive deforestation, [22,69]. Pastoral land in New Zealand has even been converted back to forest by allowing it to be colonized by wild Manuka shrubs [24]. In the case of the natural reclamation of pastoral fields by wild Manuka plants, microclimate changes have been observed to facilitate succession and reforestation [24].

A major limitation to using Manuka in the Sahel is the fact that it is not native to the region. Manuka would be an invasive species and for that reason alone should be avoided in planning. However, Manuka has been extensively studied and provides a good example of the type of traits that must be found in a native species. There are several African shrub species with similar traits that could likely be used in a revised GGW. There are a number of native species that are known to grow fast in arid and semi-arid conditions on poor quality soil, that grow to a suitable height to form a wind break and that could be used as nursery plants. One example is Hanza (Boscia senegalensis). This shrub is found natively throughout the Sahel, produces flowers and produces ripe fruit at the beginning of the rainy season. This is the time in which sustenance farmers are most vulnerable, as they are only beginning to plant their crops [70]. Other species include raisin bush (Grewia flava), common Guarri (Euclea undulata) and blue bush (Diospyros lycioides). These are all shrubs that, in addition to producing flowers, also produce edible fruits and other valuable products, including wood products. The use of these shrubs for producing honey is not yet understood, however, and would have to be examined before they are incorporated into the GGW.

The ability of selected shrubs to form the basis of honey production is an important consideration. With global demand for medicinal honey products increasing, this is an area in which a growing industry could be developed. Additionally, the local production of medical honey products would ensure that these products would be available to communities and countries across the Sahel. Therefore, this would not only provide economic benefits through developing industry, but could also increase medical resources and treatment options for local peoples, as the medicinal properties of honey could be taken advantage of and used in lieu of and to compliment traditional medicine. In addition to providing honey ingredients for pharmaceutical and healthcare applications, the inclusion of apiaries could have significant global implications. Recently, there have been widespread observations of colony collapse disorder with incredible levels of destruction in bee populations [71]. This is a pressing concern, as bee pollination accounts for U.S. \$15 billion of crop yield each year in the U.S. alone [72]. Isolated Sahel plantations could therefore be used as a quarantine or to isolate healthy populations of honeybees that could then be exported to rebuild collapsing colonies elsewhere in the world.

While the European honeybee (Apis mellifera) could be used in this industry and would have a higher economic value for exportation to areas suffering from colony collapse, the African honeybee would be preferential. There would be several distinct advantages to using African honeybees (Apis mellifera scutellata) that make it a more viable option than the European honeybee. Firstly, the African honeybee is already adapted to the climate and is able to survive in the temperature regime that these areas can expect following climate change [73]. African honeybees appear to maintain a range of $4.2 \mathrm{~km}^{2}$, meaning that so long as hives were planted in areas where the majority of the vegetation was the flowering shrubs, 
monoculture honey could be assured [74]. As the proposed wall is $5 \mathrm{~km}$ wide, apiaries could be placed in the middle of the wall to ensure that the nectar sources are the flowering shrubs. Additionally, the African honeybee is a more aggressive species of bee than the European one [74]. This would help to prevent the poaching of the apiaries or of the shrub wood, although the more aggressive nature of the bees could be a concern for farmers and herders; however, these individuals could be trained in how to avoid disturbing the bees and how to react to disturbed hives [74]. These trained individuals would likely be the locals who would also have an ownership and care-taking role with respect to the apiaries and would have required this training to be able to harvest the honey.

One essential component of this plan is to ensure local involvement and local ownership [75,76]. Individuals who are seeing direct personal gains from these programs will be more likely to protect them and to encourage them $[75,76]$. Through communication, interaction and education programs with local communities and individuals along the length of the GGW project, it should be possible to gain support for this program. There are several assessments that must be completed at the local level to ensure the success of this program [75,76]. Continuous inclusion of local people in every step of the process, from planning to implementation and maintenance, is important for creating local ownership [76].

\section{Conclusions}

In this paper, we argue that if the proposed Great Green Wall for addressing desertification in the Sahel is to be effective, then there needs to be an enhanced focus on the planting of shrubs as opposed to trees. Drawing upon research and successful desertification remediation schemes elsewhere, we show that using shrubs has several advantages, including their higher growth rates as early colonizing plants, silvo-pastoral systems around honey production that they can support and their pre-adaptation to climate change impacts projected for the region. While Manuka is the most widely researched shrub, it is not native to the Sahel, with several alternative species, including Hanza, raisin bush, common Guarri and blue bush, offering alternatives, albeit with the need for further study to examine their suitability. By incorporating such shrubs in desertification control, we demonstrate how this could aid in the recovery of agricultural land, create secondary industries through honey and pharmaceutical products, restore and improve pastoral lands and help protect natural habitat from grazing.

\section{Author Contributions}

David O'Connor wrote the main text and developed the proposal. James Ford was involved in the editing, organization and development of the proposal.

\section{Conflicts of Interest}

The authors declare no conflict of interest.

\section{References}

1. Intergovernmental Panel on Climate Change. Climate Change 2014: Impacts, Adaptation, and Vulnerability; Cambirdge University Press: Cambridge, UK, 2014. 
2. World Bank. World Development Report_Development and Climate Change; The World Bank: Washington, DC, USA, 2010.

3. Patt, A.G.; Tadross, M.; Nussbaumer, P.; Asante, K.; Metzger, M.; Rafael, J.; Goujon, A.; Brundrit, G. Estimating least-developed countries' vulnerability to climate-related extreme events over the next 50 years. Proc. Natl. Acad. Sci. USA 2010, 107, 1333-1337.

4. Costello, A.; Abbas, M.; Allen, A.; Ball, S.; Bellamy, R.; Friel, S.; Groce, N.; Johnson, A.; Kett, M.; Lee, M.; et al. Managing the health effects of climate change. Lancet 2009, 373, 1693-1733.

5. Speranza, C.I.; Scholz, I. Special issue "adaptation to climate change: Analysing capacities in africa". Reg. Environ. Chang. 2013, 13, 471-475.

6. Kilroy, G. A review of the biophysical impacts of climate change in three hotspot regions in Africa and Asia. Reg. Environ. Chang. 2014, in press.

7. Bizikova, L.; Parry, J.; Dekens, J.; Echieverria, D. Review of key initiatives and approaches to adaptation planning at the national level in semi-arid areas. Reg. Environ. Chang. 2014, in press.

8. Fankhauser, S.; Burton, I. Spending adaptation money wisely. Clim. Policy 2011, 11, 1037-1049.

9. Sovacool, B.K.; D’Agostino, A.L.; Meenawat, H.; Rawlani, A. Expert views of climate change adaptation in least developed Asia. J. Environ. Manag. 2012, 97, 78-88.

10. Sovacool, B.K. Expert views of climate change adaptation in the maldives. Clim. Chang. 2012, 114, 295-300.

11. Mannke, F. Key themes of local adaptation to climate change: Lessons from mapping communitybased initiatives in Africa. In Experiences of Climate Change Adaptation in Africa; Leal Filho, W., Ed.; Springer: Heidelberg, Germany, 2011; pp. 17-32.

12. Berrang-Ford, L.; Ford, J.D.; Patterson, J. Are we adapting to climate change? Glob. Environ. Chang. 2011, 21, 25-33.

13. Biagini, B.; Bierbaum, R.; Stults, M.; Dobardzic, S.; McNeeley, S.M. A typology of adaptation actions: A global look at climate adaptation actions financed through the global environment facility. Glob. Environ. Chang. 2014, 25, 97-108.

14. Mannke, F. An Overview of Community-Based Adaptation to Climate Change in Africa; The Arkleton Trust: Streatly, UK, 2010; p. 144.

15. Ford, J.D.; Berrang-Ford, L.; Bunce, A.; Mckay, C.; Irwin, M.; Pearce, T. The current status of climate change adaptation in Africa and Asia. Reg. Environ. Chang. 2014, in press.

16. Su, Y.Z.; Zhao, W.Z.; Su, P.X.; Zhang, Z.H.; Wang, T.; Ram, R. Ecological effects of desertification control and desertified land reclamation in an oasis-desert ecotone in an and region: A case study in Hexi Corridor, northwest China. Ecol. Eng. 2007, 29, 117-124.

17. Castro, J.; Zamora, R.; Hódar, J.A. Restoring Quercus pyrenaica forests using pioneer shrubs as nurse plants. Appl. Veg. Sci. 2006, 9, 137-142.

18. Gómez-Aparicio, L.; Gómez, J.M.; Zamora, R.; Boettinger, J.L. Canopy vs. Soil effects of shrubs facilitating tree seedlings in mediterranean montane ecosystems. J. Veg. Sci. 2005, 16, 191-198.

19. Gómez-Aparicio, L.; Zamora, R.; Gómez, J.M.; Hódar, J.A.; Castro, J.; Baraza, E. Applying plant facilitation to forest restoration: A meta-analysis of the use of shrubs as nurse plants. Ecol. Appl. 2004, 14, 1128-1138.

20. Van Auken, O.W. Shrub invasions of north American semiarid grasslands. Annu. Rev. Ecol. Syst. 2000, 31, 197-215. 
21. Vetaas, O.R. Micro-site effects of trees and shrubs in dry savannas. J. Veg. Sci. 1992, 3, 337-344.

22. Rufaut, C.; Craw, D. Geoecology of ecosystem recovery at an inactive coal mine site, New Zealand. Environ. Earth Sci. 2010, 60, 1425-1437.

23. Hedley, C.B.; Lambie, S.M.; Dando, J.L. Edaphic and environmental controls of soil respiration and related soil processes under two contrasting manuka and kanuka shrubland stands in North Island, New Zealand. Soil Res. 2013, 51, 390-405.

24. Funk, J.; Kerr, S. Restoring forests through carbon farming on Māori land in New Zealand/Aotearoa. Mt. Res. Dev. 2007, 27, 202-205.

25. Liu, S.L.; Fu, B.J.; Lü, Y.H.; Chen, L.D. Effects of reforestation and deforestation on soil properties in humid mountainous areas: A case study in Wolong Nature Reserve, Sichuan province, China. Soil Use Manag. 2002, 18, 376-380.

26. Mitchell, D.J.; Fullen, M.A.; Trueman, I.C.; Fearnehough, W. Sustainability of reclaimed desertified land in Ningxia, China. J. Arid Environ. 1998, 39, 239-251.

27. Rasmussen, K.; Fog, B.; Madsen, J.E. Desertification in reverse? Observations from northern Burkina Faso. Glob. Environ. Chang. 2001, 11, 271-282.

28. Gonzalez, P.; Tucker, C.J.; Sy, H. Tree density and species decline in the African Sahel attributable to climate. J. Arid. Environ. 2012, 78, 55-64.

29. Fensholt, R.; Langanke, T.; Rasmussen, K.; Reenberg, A.; Prince, S.D.; Tucker, C.; Scholes, R.J.; Le, Q.B.; Bondeau, A.; Eastman, R.; et al. Greenness in semi-arid areas across the globe 1981-2007-An earth observing satellite based analysis of trends and drivers. Remote Sens. Environ. 2012, 121, 144-158.

30. United Nations Economic Commission for Africa. Africa Review Report on Drought and Desertification; United Nations Economic Commision for Africa: Addis Ababa, Ethiopia, 2008.

31. Sonneveld, B.G.J.S.; Keyzer, M.A.; Adegbola, P.; Pande, S. The impact of climate change on crop production in west Africa: An assessment for the oueme river basin in Benin. Water Resour. Manag. 2012, 26, 553-579.

32. Mortimore, M. Adapting to drought in the Sahel: Lessons for climate change. Wires Clim. Chang. 2010, 1, 134-143.

33. Mertz, O.; Mbow, C.; Nielsen, J.O.; Maiga, A.; Diallo, D.; Reenberg, A.; Diouf, A.; Barbier, B.; Moussa, I.B.; Zorom, M.; et al. Climate factors play a limited role for past adaptation strategies in west Africa. Ecol. Soc. 2010, 15, Article 25.

34. Sotelo Montes, C.; Weber, J.; Silva, D.; Andrade, C.; Muñiz, G.B.; Garcia, R.; Kalinganire, A. Growth and fuelwood properties of five tree and shrub species in the Sahelian and Sudanian ecozones of Mali: Relationships with mean annual rainfall and geographical coordinates. New For. 2014, 45, 179-197.

35. Claussen, M.; Bathiany, S.; Brovkin, V.; Kleinen, T. Simulated climate-vegetation interaction in semi-arid regions affected by plant diversity. Nat. Geosci. 2013, 6, 954-958.

36. Dekker, S.C. Palaeoclimate: Biodiversity-dominated feedback. Nat. Geosci. 2013, 6, 903-904.

37. Lambin, E.F.; D’haen, S.A.L.; Mertz, O.; Nielsen, J.O.; Rasmussen, K. Scenarios on future land changes in the west African Sahel. Geogr. Tidsskr-Den. 2014, 114, 76-83.

38. Watts, M. Silent Violence: Food, Famine, and the Peasantry in Northern Nigeria; University of California Press: Berkley, CA, USA, 1983; pp. 231-262. 
39. Watts, M. Social theory and environmental degradation: The case of Sudano-Sahelian west Africa. In Desert Development: Man and Technology in Sparselands; Gradus, Y., Ed.; D. Reidel: Dordrecht, The Netherlands, 1985.

40. Watts, M.J.; Bohle, H.G. The space of vulnerability: The causal structure of hunger and famine. Prog. Hum. Geogr. 1993, 17, 43-67.

41. Blaikie, P. The Political Economy of Soil Erosion; Methuen: London, UK, 1985.

42. Blaikie, P.; Brookfield, H. Land Degradation and Society; Meuthen: London, UK, 1987.

43. Tessema, W.K.; Ingenbleek, P.T.M.; van Trijp, H.C.M. Pastoralism, sustainability, and marketing. A review. Agron. Sustain. Dev. 2014, 34, 75-92.

44. Forestry Department. Global Forest Resources Assessment 2010: Country Report Gambia; Food and Agriculture Organization of the United Nations: Rome, Italy, 2010.

45. Brown, L.B. The Earth is Shrinking: Advancing Deserts and Rising Seas Squeezing Civilization. Available online: http://www.earth-policy.org/plan_b_updates/2006/update61 (accessed on 15 August 2014).

46. Hayashi, A.; Akimoto, K.; Tomoda, T.; Kii, M. Global evaluation of the effects of agriculture and water management adaptations on the water-stressed population. Mitig. Adapt. Strat. Gl. 2013, 18, 591-618.

47. Rasmussen, L.V.; Reenberg, A. Land use rationales in desert fringe agriculture. Appl. Geogr. 2012, 34, 595-605.

48. Meyfroidt, P.; Lambin, E.F.; Erb, K.-H.; Hertel, T.W. Globalization of land use: Distant drivers of land change and geographic displacement of land use. Curr. Opin. Environ. Sustain. 2013, 5, 438-444.

49. Food and Agriculture Organization of the United Nations. Africa's Great Green Wall Reaches out to New Partners. Available online: http:/www.fao.org/news/story/en/item/210852/icode/ (accessed on 15 August 2014).

50. Bisaro, A.; Kirk, M.; Zdruli, P.; Zimmermann, W. Global drivers setting desertification research priorities: Insights from a stakeholder consultation forum. Land Degrad. Dev. 2014, 25, 5-16.

51. Chechina, M. National tree day-How are you going to celebrate? For. Chron. 2011, 87, 461-467.

52. Roberts, D.; O'Donoghue, S. Urban environmental challenges and climate change action in Durban, south Africa. Environ. Urban 2013, 25, 299-319.

53. Reenberg, A. Insistent dryland narratives: Portraits of knowledge about human-environmental interactions in Sahelian environmen policy documents. West Afr. J. Appl. Ecol. 2012, 20, 97-111.

54. Stringer, L.C.; Dougill, A.J.; Dyer, J.C.; Vincent, K.; Fritzsche, F.; Leventon, J.; Falcao, M.P.; Manyakaidze, P.; Syampungani, S.; Powell, P.; et al. Advancing climate compatible development: Lessons from southern Africa. Reg. Environ. Chang. 2014, 14, 713-725.

55. Dang, H. Fuel substitution in sub-Saharan Africa. Environ. Manag. 1993, 17, 283-288.

56. United Nations Economic Commission for Africa. Africa's Regional Review: Report on Energy; United Nations Economic Commisssion for Africa: Addis Ababa, Ethiopia, 2005.

57. Dalling, J.W.; Hubbell, S.P. Seed size, growth rate and gap microsite conditions as determinants of recruitment success for pioneer species. J. Ecol. 2002, 90, 557-568. 
58. D’Odorico, P.; Fuentes, J.D.; Pockman, W.T.; Collins, S.L.; He, Y.; Medeiros, J.S.; deWekker, S.; Litvak, M.E. Positive feedback between microclimate and shrub encroachment in the northern Chihuahuan desert. Ecosphere 2010, 1, Article 17.

59. Eldridge, D.J.; Bowker, M.A.; Maestre, F.T.; Roger, E.; Reynolds, J.F.; Whitford, W.G. Impacts of shrub encroachment on ecosystem structure and functioning: Towards a global synthesis. Ecol. Lett. 2011, 14, 709-722.

60. Castro, J.; Zamora, R.; Hódar, J.A.; Gómez, J.M. Use of shrubs as nurse plants: A new technique for reforestation in Mediterranean mountains. Restor. Ecol. 2002, 10, 297-305.

61. Luo, H.; Oechel, W.C.; Hastings, S.J.; Zulueta, R.; Qian, Y.; Kwon, H. Mature semiarid chaparral ecosystems can be a significant sink for atmospheric carbon dioxide. Glob. Chang. Biol. 2007, 13, 386-396.

62. Fang, J.; Guo, Z.; Piao, S.; Chen, A. Terrestrial vegetation carbon sinks in China, 1981-2000. Sci. China Ser. D Earth Sci. 2007, 50, 1341-1350.

63. DeMalach, N.; Kigel, J.; Voet, H.; Ungar, E.D. Are semiarid shrubs resilient to drought and grazing? Differences and similarities among species and habitats in a long-term study. J. Arid. Environ. 2014, $102,1-8$.

64. Yaghoobi, R.; Kazerouni, A.; Kazerouni, O. Evidence for clinical use of honey in wound healing as an anti-bacterial, anti-inflammatory anti-oxidant and anti-viral agent: A review. Jundishapur J. Nat. Pharm. Prod. 2013, 8, 100-104.

65. Irish, J.; Blair, S.; Carter, D.A. The antibacterial activity of honey derived from Australian flora. PLoS One 2011, 6, e18229, doi: 10.1371/journal.pone.0018229.

66. Du Toit, D.F.; Page, B.J. An in vitro evaluation of the cell toxicity of honey and silver dressings. $J$. Wound Care 2009, 18, 383-389.

67. Khan, F.R.; Abadin, Z.U.; Rauf, N. Honey: Nutritional and medicinal value. Int. J. Clin. Pract. 2007, 61, 1705-1707.

68. Dawson, J.; Lucas, R. Nature Guide to the New Zealand Forest; Godwit: Auckland, New Zealand, 2000.

69. Rufaut, C.; Clearwater, S.; Craw, D. Recolonisation and recovert of soil invertebrate assemblages at an inactive coal mine in southern New Zealand. N. Z. Nat. Sci. 2010, 35, 17-30.

70. Challinor, A.; Wheeler, T.; Garforth, C.; Craufurd, P.; Kassam, A. Assessing the vulnerability of food crop systems in Africa to climate change. Clim. Chang. 2007, 83, 381-399.

71. Anonymous. Bee Colony Collapse Disorder. Available online: http://npic.orst.edu/envir/ccd.html (accessed on 16 March 2014).

72. Anonymous. Honey Bees and Colony Collapse. Available online: http://www.ars.usda.gov/ News/docs.htm?docid=15572 (accessed on 10 October 2014).

73. Schneider, S.S.; Hoffman, G.D.; Smith, D.R. The African honey bee: Factors contributing to a successful biological invasion. Annu. Rev. Entomol. 2004, 49, 351-376.

74. McNally, L.C.; Schneider, S.S. Spatial distribution and nesting biology of colonies of the African honey bee Apis mellifera scutellata (Hymenoptera: Apidae) in Botswana, Africa. Environ. Entomol. 1996, 25, 643-652. 
75. Agrawal, A.; Perrin, N. Climate adaptation, local institutions and rural livlihoods. In Adapting to Climate Hcange: Thresholds, Values, Governance; Adger, W.N., Lorenzoni, I., O’Briend, K.L., Eds.; Cambridge University Press: Cambridge, UK, 2009.

76. Mearns, R.; Norton, A. Social Dimensions of Climate Change: Equity and Vulnerability in a Warming World; World Bank: Washington, DC, USA, 2010; pp. xxiii, 319.

(C) 2014 by the authors; licensee MDPI, Basel, Switzerland. This article is an open access article distributed under the terms and conditions of the Creative Commons Attribution license (http://creativecommons.org/licenses/by/4.0/). 